\title{
The Effect of Different Types of Repeated Performance (Private Vs Public) as Post-Task Activities on The English Students' Accuracy and Fluency in L2 Oral Production
}

\author{
Hossein Khodabakhshzadeh $^{1, a}$, Bi Bi Simin Mousavi ( Statistic counselor) ${ }^{2, b}$ \\ ${ }^{1}$ Islamic Azad University, Torbat -e- Heydarieh Branch, Torbat -e- Heydarieh, Iran \\ ${ }^{2}$ Khorasan Razavi Education Organization \\ ahkhodabakhshzade@gmail.com, bsmousavi91@gmail.com
}

\begin{abstract}
This study aims at investigating the effect of post-task activities on the TEFL students' fluency and accuracy in oral production. In particular, the study seeks to discover the effect of different types of repeated performance (i.e., public and private) as posttask activities on fluency and accuracy of oral production. Our premise is in line with Ellis's (1994) idea that these types of activities can promote learning. The participants were all TEFL students studying at Iranian universities and institutes. They were assigned into four groups. They all participated in pre and post interview sessions. The students in group A repeated their performance in private. The students in group B repeated their performance in front of the class and the students in group $\mathrm{C}$ as the last experimental group repeated their performance both in public and private. The students in group D as the control group didn't have any repeated performance. The results indicated that group B outperformed all other groups in fluency. Concerning accuracy, the students in group C outperformed the students in all other groups.
\end{abstract}

Index Terms-Post-task, Fluency, accuracy

\section{Introduction}

Task based language teaching (TBLT) has recently become a widespread approach in many educational settings (Nunan, 2003; Carless, 2004; Littlewood, 2007;). Littlewood (2004) states that:

The task-based approach has achieved something of status of a new orthodoxy: teachers in a wide range of settings are being told by curriculum leaders that this is how they should teach, and publishers almost everywhere are describing their new textbooks as task-based. Clearly, whatever a task-based approach means, it is a good thing. (p. 319)

There has also been an steady increase in the number of studies in which tasks are the organizing unit of learning activity (Bygate, Skehan, and Awain, 2001; Ellis, 2003). Ellis (2009) believes that TBLT has drawn extensively on research into L2 acquisition.

TBLT considers 'task' as the basic unit on which designing of a lesson is based. Besides all the characteristics that a task should have (i.e. meaning, gap, need for learners' resources, etc), it should be clearly distinguished from other types of activities such as 'situational grammar exercises'. TBLT also entails both design and methodology. Ellis (2009) speculates that decisions should be made regarding the types of tasks we include in a course, the content of the tasks, and the way of sequencing the tasks to facilitate learning. He also states that methodological decisions concern how to structure a task-based lesson and what type of participatory structure to employ. A task based lesson according to Ellis (2009) has three phases ( pretask phase, The main task phase and the post-task phase). There are different modes for the performance based on the types of tasks and phases. Tasks can be performed in a whole-class context, in pairs, in groups, or by learners working individually.

Contrary to the emphasis, which has been put on the main phase, here in this project we want to attract the attention of practitioners towards the crucial role that other phases especially post-task phase which has traditionally been ignored, can play. According to Ellis (2003) Post-task phase provides an opportunity for a repeated performance, encourages reflection on how the task was performed and encourages attention to form in particular to those forms that proved problematic to the learners when they performed the task.

Several studies (Bygate, 1996; Lynch and McLean, 2001) indicate that when learners repeat a task their production improves in a number of ways, for example, complexity increases, propositions are expressed more clearly, and they become more fluent. It seems that carrying the performance for the second time will increase the chance of being more exact and fluent. There has been no research comparing the learner production.

\section{Review of The Related Literature}

\section{A. Task Based Language Teaching and Learning}

The concept of TBLT was first introduced by Prabhu (1987) in his Banglore Project in which he focused on communication, not on explicit grammar teaching, by engaging learners in doing 'task'. The major premise of the TBLT is that language acquisition takes place when learners negotiate meaning to perform a particular task. 
In Task-Based Language Learning (TBLL), learning is fostered through performing a series of activities as steps towards successful task realisation. The focus is away from learning language items in a noncontextualised vacuum to using language as a vehicle for authentic, real-world needs. By working towards task realisation, the language is used immediately in the real-world context of the learner, making learning authentic. In a TBLL framework the language needed is not pre-selected and given to the learners who then practise it but rather it is drawn from the learners with help from the facilitator, to meet the demands of the activities and task.

In this approach, motivation for communication becomes the primary driving force. It places the emphasis on communicative fluency rather than the hesitancy borne of the pressure in more didactic approaches to produce unflawed utterances. Exposure to the target language should be in a naturally occurring context. This means that, if materials are used, they are not prepared especially for the language classroom, but are selected and adapted for authentic sources.

\section{B. Improving Fluency of Second Language Learners}

Fluency is not an easy concept to define. According to Derwing, T., Rossiter, M. \& Thomson, R. (2004) the difficulty in achieving a definition lies in the fact that fluency encompasses many aspects of language. Hartmann \& Stork (1976) believe that a fluent speaker of a language can use its structures accurately whilst concentrating on content rather than form, using the units and patterns automatically at normal conversational speed when they are needed. Brumfit (1984) states that fluency is to be regarded as natural language use. Richard et al. (1985) maintain that fluency is the features which give speech the qualities of being natural and normal, including native-like use of pausing, rhythm, intonation, stress, rate of speaking, and use of interjections and interruptions.

Improving the students' oral fluency is one of the challenging issues for language teachers. This is one of the most difficult challenges in teaching an L2 is finding ways to help students improve their oral fluency. This is especially true in countries where learners share a common mother tongue and have little or no exposure to the L2 outside the classroom. According to Bresnihan \& Stoops (1996), pair and group work communication tasks - as they are structured in ESL classrooms - are often ineffective or not as effective as teachers desire. The reason is simple; when learners are asked to perform these activities, they often just chat in their native language. Although they may want to express their ideas in English, it is hard for them to do so, and it is hard for teachers to convince them to try. Schneider (1997) proposes a solution to this problem by focusing exclusively on fluency and making students communicate with English Fluency only. Schneider explains that the only outcome of the years is an extensive knowledge of grammar and vocabulary that is rarely put into oral practice. One way to avoid this problem is to make students focus on English and try to improve their fluency. This method may also activate in them the prime motivators for language learning: gaining increased satisfaction from studying a new language and a heightened sense of appreciation of its relevancy to their lives.

There are mostly some basic strategies that are widely utilized to improve the level and content of learners' oral fluency. Teachers and researchers around the world utilize these fluency-enhancing strategies. Speech rate is the one that is considered to be a sound indicator of fluency (Wood, 2001). Muntro and Derwing (1998) tested the hypothesis that accented speech heard at a reduced rate would sound less accented and more comprehensible than speech produced at a normal rate.

Turk (1995) believes that the pace of the human speaking voice can be consciously varied. He reassures anyone concerned about his or her pace of speech, even non-fluent speakers, to relax about constantly feeling the need to speed up. He also argues that varied-pace method adds to the attractiveness of the speaking voice. Other scholars also believe that it is important to vary one's speech rate as situation warrants. (Porter \& Grant, 1992). According to them, however, non-natives worry that they lack fluency in English and, may speak quickly to make up for it.

They distinguish between different uses of spoken language I which one has to watch the speed of speech. They suggest that the rate of spoken language for the sake of transaction shouldn't be that much high so that for example students loose the track of their professors' speech. They speculate however that in interactional function, where the spoken language is speeded up in conversations of social nature. But fast speech is not necessarily fluent speech. In fact, fluent native speakers vary their speed depending on the context in which they are speaking. Unfortunately, non-native speakers often think that they should speak fast to be more fluent. Hence, L2 learners must realize that it is fine to speak slowly as long as it is done at a reasonable rate. Such rate is achieved when speakers, both native and nonnative, have time to think as they talk.

The reduced form of speech such as contraction usually has a positive influence on speeding up one's rate of speech (Tam, 1997). Fluent speakers also produce sentences that appear in elliptical forms. As such, when the context is obvious, subjects, articles, verbs, pronouns, etc., are frequently deleted. Brown (2003) also adds several other subcategories including weak forms, linking, assimilation, and intrusion. He believes that these reduced forms are not the signs of lazy or careless English. He also maintains that spoken English is very different from written English, and that teachers shouldn't be surprised when their students are unable to understand natural spoken language, like, "whenduyawannagonnagedoudahere?"

[ When do you want to get out of here?] (p. 4). 
L2 learners would get enough oral practice from a communication course (Tam, 1997). This rehearsed practice provides the participants with enough preparation to give technical talks in English. In this study Tam mingled super segmental elements with fluency practice. He emphasized on repetition, proper use of discourse markers, prosodic cues and cohesive links. By encouraging repetition of utterances, focusing on voice quality, and reduced forms in speech, the course's pedagogic implication was that fluency training is an achievable endeavor.

Bresnihan and Stoops (1996) state that in countries where students share a common L1, finding ways to help students improve their fluency is an important issue. They found that some activities such as "Talking Zone", "Speaking Line", and "Conversation Game" were very effective in encouraging Japanese to speak in English, even in large classrooms.

Fluency is not a matter of simple concept to be defined in a straight forward way. Oral fluency is one of the most salient markers of proficiency in a second language. The term 'fluency' has a range of meanings, the most common of which is related to 'high proficiency,' that is, an excellent grasp of the vocabulary and grammar of a language. According to Nation (2001) and Adolphs and Schmitt (2004), being fluent implies that up to $90 \%-95 \%$ of the speech produced by an English speaker is bound to be composed out of the same 2,000 high frequency word families, that is, a comparatively small subset of the English lexicon.

Fluent speakers also rely on automatic knowledge of common collocates, frames, and other structures in order to avoid improvising language anew every time they speak (Ellis, 2001; McLaughlin, 1990; and Lewis, 2002).

Non-fluent speakers of a language would require explicit selection of the grammatical forms involved, together with deliberate selection of vocabulary, before they finally come to decide on how to assemble all the elements together. The speakers undergo a creative process through which they try to compensate for their lack of fluency and it forces them to produce a grammatically correct sentence that, nonetheless, sounds strange, or perhaps incomprehensible, o fluent speakers.

Scholars believe that fluent speakers rely on a database of memories of utterances, (Ellis, 2001), on prefabricated linguistic material, (Lewis, 2002; Schmit and Carter, 2004) and on internalized lexical phrases and chunks, (Nation, 2001).

As a matter of fact, it is not logical to say that because we rely on automatic knowledge of a language to express ourselves successfully we shouldn't think about any degree of improvisation. However, the creative aspect of language production comes with a high processing price that requires verbal dexterity.

This is actually what learners lack and the situation learners are in when acquiring a language. That is to say, as learners we are forced to be creative, we are forced to improvise nearly all of the time.

\section{The Framework of Fluency}

The conceptual framework of the fluency can be categorized into four sections: linguistic, cognitive, interactional, and affective. The linguistic element identifies a concrete subset of the language, namely, high frequency words and collocates as well as productive frames and lexical phrases. According to a study undertaken by Adolphs and Schmitt (2004), up to $90 \%-95 \%$ of daily spoken discourse is constructed from the 2,000 most frequent word families in English. This fact alone cannot be dismissed at any level of language education and is paramount when addressing fluency. The implications should be clear. MacLaughlin (1990) in his restructuring theory states that we move from words to collocates, building larger and larger blocks.

Internalization and retrieval are two fundamental cognitive element, that make fluency feasible. Without a database of linguistic structures to draw from and without the capacity to retrieve them in a timely fashion, fluent speech is not possible. Fluent use of language does not rely on grammar in the sense of abstract rules but, rather, on a huge collection of previously experienced utterances (Ellis, 2001). What makes the knowledge of vocabulary is not just the phonological and semantic but also the collocation. Word knowledge is not just composed of phonological and semantic poles but also includes collocational knowledge.

The interactional element identifies the effective collaboration as both listener and speaker to be the product of concrete patterns that go beyond the linguistic elements previously mentioned. Successful fluent communication between interlocutors requires parties to conform to certain expectations. Speaker interaction relies on topic management and turn taking strategies, as well as the timely delivery of, among other things, appropriate and fixed linguistic responses, namely, adjacency pairs (Hedge, 2000).

There are also some other elements such as selfesteem, inhibition, language ego, extroversion, empathy, stress, etc, that have been distinguished by Brown (2000) to be influential, if not crucial, to performance regardless of the level of proficiency. Fluent speakers' speech can be halted, broken, even incomprehensible by feelings of intensity, negative self-perception, or self-doubt.

Conversly, feelings of confidence, self-assurance, or lack of inhibition can disguise limitations in the speech of a speaker of moderate fluency and capacity.

The logical sum of what was mentioned can be one cannot produce fluent speech without the adequate words, collocates, and frames, without the ability to retrieve these in a timely fashion, without the knowhow to manage interaction, and without a certain psychological disposition.

Language use is a profoundly convergent process, that is, it strongly tends toward redundancy and replication. It may appear strange, for some, that language use is so formulaic but the data is unequivocal. Input and interaction theory assumes this observation as it relies on an inherent tendency of learners to conform to the input they receive in order to 
further development. Just as a fluent speaker produces the phrase "take a deep breath" automatically, the exposure to the phrase provides learners with a prompt to do so themselves.

Again, although learners are forced to improvise most of the time, they are nonetheless as implicitly aware as fluent speakers are of the desirability of conventional forms over improvised ones. It is, in fact, this convergent and inherent drive within fluent speakers that makes a phrase such as "take a deep breath" to be formulaic since, otherwise, fluent speakers themselves would divert and improvise phrases of equal meaning when wanting to say "take a deep breath”. In other words, fluent speakers naturally tend toward convention and so do learners.

Automatizing the receptive and productive retrieval is an important cognitive element. It, in fact, strengthens the associations within the boundaries of a single word and across words. MacLaughlin's (1990) restructuring theory proposes that learned responses are the product of consistent mapping of the same input to the same pattern of activation over many trials. Nation (2001) states that "restructuring occurs when learners reach a high degree of automatisation through practice" (p. 337). Similarly, Ellis (2006) posits that each encounter serves to strengthen the association previously made, building a memory storage of concrete utterances.

As the interlocutors share the information, they reach a settlement or progress towards a goal they are involved in the interactional process which is quite dynamic. Hedge (2000) explains that "the ability to respond coherently within the turns of conversation, to link the words and phrases of questions ..... is what constitutes fluency” (p. 54).

There are some definite structures such as adjacency pairs taking the form of question-answer, invitationacceptance/refusal pairs, greeting pairs, and so on that determine the course of interaction (Schegloff and Sacks, 1973). When a speaker says something, a preferred response is expected not only in terms of content but also in terms of structure. For example, to reply to a greeting with a refusal is unexpected as greetings create a slot for the next person to fill with another greeting.

The psychological factors as Brown (2000) believes, make us think that learners are not abstract entities but human beings with feelings about themselves and the people they come into contact with. Ignoring this issue will cause more and more of insecurity, anxiety and inhibition in learners. When someone feels stress, there are definite, almost palpable, physical changes taking place. Schumann (1999) attributes the cognitive connections between affect and language learning to a particular section of the temporal lobes. Brown (2000) elaborates on this by explaining that when learners are required to respond in ways they perceive to be beyond their capabilities, their brains send signals to indicate that the stimulus is unpleasant, unmanageable, and a potential threat to self-esteem.

\section{Method}

\section{A. Participants}

A total number of 45 students from among 55 participants were randomly assigned in to three groups after taking the interview section of the IELTS.

All participants showed interest to take part in this study.

Group A consisted of 15 (male and female) ranging in age from 19-24.

Group B consisted of 12 males ranging in age from 19-23.

Group C consisted of 13 males ranging from 18-23.

15 students were the members of the control group.

\section{B. Materials}

Interview section of the IELTS was used for assessing the students' oral performance both in pre and post tests.

The material for instruction was Interchange 3 as the text book of instruction.

\section{Procedure}

All of the participants took part in an interview as a pe-test. They were assigned in to four groups and the first three groups as the experimental ones received conversation instruction at the advanced level. The instruction in all of the experimental groups was taskbased.

In fact the instruction went through and reflect the chronology of a task-based lesson (Ellis, 2003). The first phase which was pre-task concerns the various activities for whetting students' appetites to perform the task (Dornyei, 2001).

The second phase was during-task which was also common among all groups. Ellis (2003) stipulates two methodological options for this phase. i.e. task performance and process option. In this categorization Ellis (2003) considers three task performance options. The first one concerns time limitation to perform the task. The second performance option involves deciding whether to allow the students access to the input data while they perform a task. The last task performance option consists of introducing some surprise elements into the task.

The instructors in all groups were informed about these steps and they were required to follow them in their conversation instruction.

The last phase of this task-based instruction was post-phase which was the main concern of this study. In all of the three experimental groups students repeated performance but in different forms.

In group A students repeated their performance privately i.e. just for the teacher in a face to face conference.

In group B students repeated their performance publicly in front of the class.

In group $\mathrm{C}$ students repeated their performance both publicly and privately.

In group $\mathrm{D}$ which is the control group the students didn't have any repeated performance in the post-task phase. 
The first three groups have finished the treatment period and took part in the post interview session. The interview sessions were recorded and the data were gathered according to the models of fluency and accuracy mentioned earlier.

\section{Data Collection}

All participants in different groups took part in oral examinations as pre and post-tests.

\section{A. Data Analysis}

For the purpose of analysis, we used the data related to each participant in details.

Both in fluency and accuracy as it is shown in tables 1-8.

The procedures for raw data analysis were the following:

1. Total number of syllables per turn. This measure (Temple, 1992) includes the number of syllables produced by each turn and includes syllables produced in English words (i.e., common - 2 syllables; disaster 3 syllables). Filled pauses (i.e., ah, ahm, eh, ehm, uh, uhm \& $\mathrm{mmm}$ ) were not included in this measure.

2. Total number of seconds per turn. This measure (Temple, 1992) was obtained by measuring every turn in seconds. The software used was SoundScriber. This measure includes the time taken to produce the whole turn including words, filled pauses, and silent pauses.

3. Rate of speech in syllables per second (inclusive). Following previous investigations of speech rate (Binnenporte et al., 2005; Towell et al., 1996), the inclusive speech rate (i.e., total length of utterance including pauses) was calculated by dividing the total number of syllables produced in each turn (see 1, above) by the number of seconds taken to produce it. This measure also included all the syllables contained in repetitions, repairs and lexical fillers (i.e., discourse markers such as "ok", and "in other words" among others).

4. Rate of speech adjusted. This measure was adapted from Freed et al. (2004), who measured speech rate in words per minute and excluded false starts, repetitions, partial repetitions, and items contained in repairs. In the current study, I measured syllables instead of words in order to account for the different lengths of words in English. The formula that was used is detailed here:

$$
\text { rate of speech adjusted }=\frac{\text { sy.l. }- \text { (syllin repeated segment }+ \text { sylli.in repaired segment) }}{\text { seconds }}
$$

5. Filled Pauses. Filled pauses (i.e., uh, uhm, mmm, $a h, a h m, e h \& e h m$ ) were counted for every turn (Chafe 1980, Dechert 1980, Raupach, 1980, Freed et al. 2004).

6. Repetitions. This measure was derived from Freed et al. (2004) and reflected all the repetitions that appeared in each turn. Repetitions were counted as units. For example: "when, I was, when I was to do my, applications to the university ahm" would count as one repetition.

7. Repairs. This measure of fluency was derived from Freed et al. (2004) and reflected the number of repairs as units used per turn. Examples of repair include grammar correction samples: "I want to go (the-fem) next month (masc. noun), (the-masc) next month (masc. noun) (= 1 self correction).”

Regarding the statistical analysis, different statistical procedures were utilized to answer the research questions. The fluency and accuracy measures were the focal point in these analysis. In order to compare the participants' fluency and accuracy performance within groups, a sample paired t-test was performed for each group separately. For the sake of between group comparisons, we used different multivariate (MANOVA) tests. The results can be observed in tables 1-6.

TABLE 1

ONE-SAMPLE TEST

\begin{tabular}{|c|c|c|c|c|c|c|}
\hline & \multicolumn{6}{|c|}{ Test Value $=0$} \\
\hline & \multirow[b]{2}{*}{$\mathrm{T}$} & \multirow[b]{2}{*}{ Df } & \multirow[b]{2}{*}{ Sig. (2-tailed) } & \multirow[b]{2}{*}{ Mean Difference } & \multicolumn{2}{|c|}{ 95\% Confidence Interval of the Difference } \\
\hline & & & & & Lower & Upper \\
\hline $\begin{array}{l}\text { Fluency } \\
\text { posA }\end{array}$ & 75.286 & 14 & .000 & 2004.00667 & 1946.9158 & 2061.0975 \\
\hline $\begin{array}{l}\text { Fluency } \\
\text { preA }\end{array}$ & $\begin{array}{r}104.56 \\
7\end{array}$ & 14 & .000 & 1530.33200 & 1498.9433 & 1561.7207 \\
\hline $\begin{array}{l}\text { Fluency } \\
\text { preB }\end{array}$ & 93.196 & 11 & .000 & 1546.04500 & 1509.5327 & 1582.5573 \\
\hline $\begin{array}{l}\text { Fluency } \\
\text { posB }\end{array}$ & 62.183 & 11 & .000 & 2257.54500 & 2177.6386 & 2337.4514 \\
\hline $\begin{array}{l}\text { Fluency } \\
\text { preC }\end{array}$ & 72.909 & 12 & .000 & 1502.05615 & 1457.1685 & 1546.9438 \\
\hline $\begin{array}{l}\text { Fluency } \\
\text { posC }\end{array}$ & 54.198 & 12 & .000 & 2025.58769 & 1944.1571 & 2107.0182 \\
\hline $\begin{array}{l}\text { Fluency } \\
\text { preD }\end{array}$ & $\begin{array}{r}132.66 \\
5\end{array}$ & 14 & .000 & 1522.86000 & 1498.2400 & 1547.4800 \\
\hline $\begin{array}{l}\text { Fluency } \\
\text { posD }\end{array}$ & 57.711 & 14 & .000 & 1765.74680 & 1700.1239 & 1831.3697 \\
\hline
\end{tabular}


The results in table 1 show a significant difference between pre and post-test of fluency in all groups.

In group $\mathrm{A}$, since $\mathrm{t}(14)=75.286$, and $P$-value $=$ 0.000 , the difference between the participants' fluency after a private repeated performance was significant which means that the repeated performance in the form of private as a post-task activity had a significant effect on the participants' fluency measurement.

In group $\mathrm{B}$, since $\mathrm{t}(11)=93.196$, and $P$-value $=$ 0.000 , the difference between the participants' fluency after a public repeated performance was significant which means that the repeated performance in the form of public as a post-task activity had a significant effect on the participants' fluency measurement.

In group C, since t $(12)=72.909$, and $P$-value $=$ 0.000 , the difference between the participants' fluency after both private and public repeated performance was significant which means that the repeated performance in the form of both private and public as a post-task activity had a significant effect on the participants' fluency measurement.

In group $\mathrm{D}$, since $\mathrm{t}(14)=132.665$, and $P$-value $=$ 0.000 , the difference between the participants' performance in post-task phase was significant.

TABLE 2

ONE-SAMPLE TEST

\begin{tabular}{|c|c|c|c|c|c|c|}
\hline & \multicolumn{6}{|c|}{ Test Value $=0$} \\
\hline & \multirow[b]{2}{*}{$\mathrm{t}$} & \multirow[b]{2}{*}{ Df } & \multirow[b]{2}{*}{ Sig. (2-tailed) } & \multirow[b]{2}{*}{ Mean Difference } & \multicolumn{2}{|c|}{ 95\% Confidence Interval of the Difference } \\
\hline & & & & & Lower & Upper \\
\hline $\begin{array}{l}\text { Accuracy } \\
\text { preA }\end{array}$ & 29.925 & 14 & .000 & 48.77333 & 45.2777 & 52.2690 \\
\hline $\begin{array}{l}\text { Accuracy } \\
\text { posA }\end{array}$ & 38.014 & 14 & .000 & 94.81267 & 89.4632 & 100.1621 \\
\hline $\begin{array}{l}\text { Accuracy } \\
\text { preB }\end{array}$ & 34.242 & 11 & .000 & 49.44750 & 46.2692 & 52.6258 \\
\hline $\begin{array}{l}\text { Accuracy } \\
\text { posB }\end{array}$ & 24.871 & 11 & .000 & 89.81917 & 81.8706 & 97.7677 \\
\hline $\begin{array}{l}\text { Accuracy } \\
\text { preC }\end{array}$ & 34.943 & 12 & .000 & 47.44846 & 44.4899 & 50.4071 \\
\hline $\begin{array}{l}\text { Accuracy } \\
\text { posC }\end{array}$ & 47.331 & 12 & .000 & 95.62462 & 91.2227 & 100.0265 \\
\hline $\begin{array}{l}\text { Accuracy } \\
\text { preD }\end{array}$ & 48.092 & 14 & .000 & 49.25400 & 47.0574 & 51.4506 \\
\hline $\begin{array}{l}\text { Accuracy } \\
\text { posD }\end{array}$ & 52.924 & 14 & .000 & 60.05267 & 57.6190 & 62.4864 \\
\hline
\end{tabular}

The results in table 2 show a significant difference between pre and post-test of accuracy in all groups.

In group $A$, since $t(14)=29.925$, and $P$-value $=$ 0.000 , the difference between the participants' accuracy after a private repeated performance was significant which means that the repeated performance in the form of private as a post-task activity had a significant effect on the participants' accuracy measurement.

In group $\mathrm{B}$, since $\mathrm{t}(11)=34.242$, and $P$-value $=$ 0.000 , the difference between the participants' accuracy after a public repeated performance was significant which means that the repeated performance in the form of public as a post-task activity had a significant effect on the participants' accuracy measurement.
In group $\mathrm{C}$, since $\mathrm{t}(12)=34.943$, and $P$-value $=$ 0.000 , the difference between the participants' accuracy after both private and public repeated performance was significant which means that the repeated performance in the form of both private and public as a post-task activity had a significant effect on the participants' accuracy measurement.

In group $\mathrm{D}$, since $\mathrm{t}(14)=48.092$, and $P$-value $=$ 0.000 , the difference between the participants' fluency in pre test and post test without any repeated performance in post-task phase was significant.

MANOVA (multivariate analysis of variance) was performed to find the the differences between groups. With regard to fluency this test indicated a significant difference between different groups. The results can be observed in tables 3 and 4 . 
TABLE 3

FLUENCY (BETWEEN-SUBJECTS EFFECT

\begin{tabular}{|c|c|c|c|c|c|c|}
\hline \multicolumn{7}{|c|}{ Multivariate Tests ${ }^{\mathrm{b}}$} \\
\hline & Effect & Value & $\mathrm{F}$ & Hypothesis df & Error df & Sig. \\
\hline \multirow{4}{*}{$\begin{array}{r}\text { Interc } \\
\text { ept }\end{array}$} & Pillai's Trace & .999 & $3.953 \mathrm{E}^{\mathrm{a}}$ & 4.000 & 11.000 & .000 \\
\hline & Wilks' Lambda & .001 & $3.953 \mathrm{E}^{\mathrm{a}}$ & 4.000 & 11.000 & .000 \\
\hline & Hotelling's Trace & $1.438 \mathrm{E} 3$ & $3.953 \mathrm{E}^{\mathrm{a}}$ & 4.000 & 11.000 & .000 \\
\hline & Roy's Largest Root & $1.438 \mathrm{E} 3$ & $3.953 \mathrm{E}^{\mathrm{a}}$ & 4.000 & 11.000 & .000 \\
\hline \multicolumn{7}{|c|}{ a. Exact statistic } \\
\hline & b. Design: Intercept & & & & & \\
\hline
\end{tabular}

TABLE 4

TESTS OF BETWEEN-SUBJECT EFFECTS

\begin{tabular}{|c|c|c|c|c|c|c|}
\hline $\begin{array}{r}\text { Sourc } \\
\mathrm{e}\end{array}$ & $\begin{array}{l}\text { Dependent } \\
\text { Variable }\end{array}$ & $\begin{array}{l}\text { Type III Sum } \\
\text { of Squares }\end{array}$ & Df & Mean Square & $\mathrm{F}$ & Sig. \\
\hline \multirow{4}{*}{$\begin{array}{r}\text { Correc } \\
\text { ted } \\
\text { Model }\end{array}$} & $\begin{array}{l}\text { totalpostestG1 } \\
\text { Fluency }\end{array}$ & $.000^{\mathrm{a}}$ & 0 & . & . & . \\
\hline & $\begin{array}{l}\text { totalpostestG2 } \\
\text { Fluency }\end{array}$ & $.000^{\mathrm{b}}$ & 0 & . & . & . \\
\hline & $\begin{array}{l}\text { totalpostestG3 } \\
\text { Fluency }\end{array}$ & $.000^{c}$ & 0 & . & . & . \\
\hline & $\begin{array}{l}\text { totalpostestG4 } \\
\text { ControlFluency }\end{array}$ & $.000^{\mathrm{d}}$ & 0 & . & . & . \\
\hline \multirow{4}{*}{$\begin{array}{r}\text { Interc } \\
\text { ept }\end{array}$} & $\begin{array}{l}\text { totalpostestG1 } \\
\text { Fluency }\end{array}$ & $6.024 \mathrm{E} 7$ & 1 & $6.024 \mathrm{E} 7$ & $5.668 \mathrm{E} 3$ & .000 \\
\hline & $\begin{array}{l}\text { totalpostestG2 } \\
\text { Fluency }\end{array}$ & 7.353E7 & 1 & 7.353E7 & $3.417 \mathrm{E} 3$ & .000 \\
\hline & $\begin{array}{l}\text { totalpostestG3 } \\
\text { Fluency }\end{array}$ & $6.205 \mathrm{E} 7$ & 1 & $6.205 \mathrm{E} 7$ & 3.865E3 & .000 \\
\hline & $\begin{array}{l}\text { totalpostestG4 } \\
\text { ControlFluency }\end{array}$ & 4.677E7 & 1 & 4.677E7 & 3.331E3 & .000 \\
\hline
\end{tabular}

Looking under the "Sig." column, we see that the main effect on fluency is significant $(p=.000)$.

The main effect of repeated oral performance on fluency was significant for all four groups $(\mathrm{F}(1,14)=$ 10628.098, $\mathrm{p}=.000)$.

Considering the mean square column, it is clearly seen that the second group (B) with the mean square of 7.353 performed the best among the other groups and groups C, A and D had an unsatisfactory performance, respectively (See table 6).

The results of multivariate analysis in table 26 can be construed in a way that different types of repeated oral performance have had different effect on the participants' fluency measurement.
Participants in group (B) who repeated their performance publicly in front of the class showed noticeable fluency improvement. The second group in this regard is group (C) whose participants had the second performance both publicly and privately. Group (A) stands in third place with respect to fluency improvement over a private repeated performance. The last one is group D without any repeated performance in post-task phase.

As it is clearly observable from the results in table 26, the participants in group B showed the highest increase in fluency measures.

The second MANOVA was performed to find the difference among the groups with respect to accuracy measures.Table 5

TABLE 5

ACCURACY (BETWEEN-SUBJECTS)

\begin{tabular}{|r|r|l|l|l|l|l|}
\hline \multicolumn{2}{|c|}{ Multivariate Tests } \\
\hline \multicolumn{2}{|r|}{ Effect } & Value & $\mathrm{F}$ & $\begin{array}{c}\text { Hypothesis } \\
\text { df }\end{array}$ & Error df & Sig. \\
\hline \multirow{3}{*}{ Intercept } & & & $2.434 \mathrm{E3}^{\mathrm{a}}$ & 4.000 & 8.000 & .000 \\
\cline { 2 - 8 } & Pillai's Trace & .999 & $2.434 \mathrm{E3}^{\mathrm{a}}$ & 4.000 & 8.000 & .000 \\
\cline { 2 - 8 } & Wilks' Lambda & .001 & $2.434 \mathrm{E3}^{\mathrm{a}}$ & 4.000 & 8.000 & .000 \\
\cline { 2 - 8 } & Hotelling's Trace & $1.217 \mathrm{E} 3$ & $2.434 \mathrm{E3}^{\mathrm{a}}$ & 4.000 & 8.000 & .000 \\
\cline { 2 - 7 }
\end{tabular}


TABLE 6

TESTS OF BETWEEN-SUBJECT EFFECTS

\begin{tabular}{|c|c|c|c|c|c|c|}
\hline $\begin{array}{r}\text { Sourc } \\
\mathrm{e} \\
\end{array}$ & $\begin{array}{r}\text { Dependent } \\
\text { Variable } \\
\end{array}$ & $\begin{array}{c}\text { Type III Sum of } \\
\text { Squares }\end{array}$ & $\overline{\mathrm{Df}}$ & Mean Square & $\bar{F}$ & Sig. \\
\hline \multirow{4}{*}{$\begin{array}{r}\text { Corre } \\
\text { cted } \\
\text { Mode } \\
1\end{array}$} & $\begin{array}{r}\text { TotalPostest } \\
\text { G1 }\end{array}$ & $.000^{\mathrm{a}}$ & 0 & . & . & . \\
\hline & $\begin{array}{r}\text { TotalPostest } \\
\text { G2 }\end{array}$ & $.000^{\mathrm{b}}$ & 0 & . & . & . \\
\hline & $\begin{array}{r}\text { TotalPostest } \\
\text { G3 }\end{array}$ & $.000^{\mathrm{C}}$ & 0 & . & . & . \\
\hline & $\begin{array}{r}\text { TotalPostest } \\
\text { G4Control }\end{array}$ & $.000^{\mathrm{d}}$ & 0 & . & . & . \\
\hline \multirow[t]{4}{*}{$\begin{array}{r}\text { Interc } \\
\text { ept }\end{array}$} & $\begin{array}{r}\text { TotalPostest } \\
\text { G1 }\end{array}$ & 105845.962 & 1 & 105845.962 & $1.077 \mathrm{E} 3$ & .000 \\
\hline & $\begin{array}{r}\text { TotalPostest } \\
\text { G2 } \\
\end{array}$ & 96809.792 & 1 & 96809.792 & 618.585 & .000 \\
\hline & $\begin{array}{r}\text { TotalPostest } \\
\text { G3 }\end{array}$ & 109063.240 & 1 & 109063.240 & $1.924 \mathrm{E} 3$ & .000 \\
\hline & $\begin{array}{r}\text { TotalPostest } \\
\text { G4Control } \\
\end{array}$ & 43970.203 & 1 & 43970.203 & $2.725 \mathrm{E} 3$ & .000 \\
\hline
\end{tabular}

The results of multivariate analysis in table 29 show that the different types of repeated oral performance have had different effect on the participants’ accuracy measurement.

Students in group $\mathrm{C}$ who repeated their performance both in public and in private, outperformed all other groups with regard to accuracy measures.

The second group that showed high accuracy in final performance was group A. Group B with a repeated public performance as a post task activity, is the third group with regard to accuracy in performance.

The last group in this regard is group D whose participants didn't have any repeated performance as a post task activity.

\section{Results and Discussion}

The fluency measures of oral performance which are reported in tables 1 to 8 as raw scores include: total spoken words, total syllables, total seconds, rate of speech adjusted, total filled pauses, total repeat, and total repair.

With regard to the total number of words produced, the range of total amount of spoken words in group A increased in pre test (298-345) to post test (450-560). The same item enjoys a higher increase in group $\mathrm{B}$ in pre-test (287-365) to post-test (521-680). Although this increase is observable in groups $\mathrm{C}$ and $\mathrm{D}$, it is not as high as the former ones.

Group B also enjoyed a higher range in the rate of speech adjusted in pre-test (0.77-0.96) to post-test (1.47-1.91). As it is observable from the tables 1-8 this increase is not as significant as the one in group $B$. Group B also enjoyed the least range of total filled pauses in post-test in comparison with pre-test (12-60 pre-test) to (2-22 post-test).The range of total repeat and total repair also decreased from pre-test (3-21 and 3-12) to post-test (0-9 and 0-3).

In sum, a gradual increase can be observed across the different groups of participants. With regard to fluency, this increase is significant on the part of group
A across all items included in fluency tables. Group B enjoys the highest increase and groups $\mathrm{C}, \mathrm{A}$, and D are in the next positions respectively.

A comparison of the total spoken words and the rate of speech adjusted in Group A to D shows that participants in group B who repeated their oral performance publicly enjoyed the highest rate of fluency with respect to these items. The participants in group B enjoyed a higher rate of total spoken words and less repetition and repair thanks to the chance of repeated performance in front of the class.

The participants in group $\mathrm{C}$ who had a chance to repeat their performance both privately and publicly stand in the second position of fluency with respect to the total spoken words and the rate of speech adjusted.

Those who repeated their performance just face to face with in a teacher-student conference stand in the third position of fluency rate, produced fewer words, and committed more pauses and repetitions.

With regard to the accuracy of speech, the results show significant difference among four groups. The participants in group $\mathrm{C}$ who had a chance to repeat their performance both in public and in private outperformed others. The participants in group A who had repeated performance were more accurate in speech than the participants in groups B and D respectively.

\section{Conclusions}

The main aim of this study was to reflect the importance and effect of different types of repeated performance as a post task activity on the EFL learners' speech fluency and accuracy.

The effect of two different types of repeated performance was tested on three different groups. A gradual improvement was observed in both fluency and accuracy of speech in these groups comparing their means in pre and post test. The comparisons between groups, however, showed significant difference between them. Regarding fluency measures, Group B 
that had a second performance in front of the class outperformed other groups. This can be interpreted as the result of communication stress reduction thanks to the public performance. The result of the private repeated performance by participants in group A didn't show any significant improvement in their fluency rates. This indicates that fluency is mostly affected by the presence of the audience. In fact, students' speech fluency is promoted as the result of the public performance. Thus, repeated public performance can be utilized as a remedy for communication stress, and increase the rate of oral fluency.

\section{Acknowledgements}

The researchers would like to thank Islamic Azad University (IAU), Torbat-e-Heydareih branch, Iran for funding this study. This is a part of a research project entitled "The Effect of Different Types of Research Performance (Prvate vs Public) as Post-Task Activities on The English Students' Accuracy And Fluency in L2 Oral Production”.

\section{References}

[1] Adolphs, S. \& Schmitt, N. (2004). Vocabulary coverage according to spoken context. In: P. Bogaards, P., Laufer, B. (Eds.), Vocabulary in a Second Language. Amsterdam: John Benjamins Publishing, pp. 39-49.

[2] Binnenporte, D., Van Bael, C., den Os, E., Boves, L. (2005). Gender in everyday speech and language: A corpus-based study. Interspeech, 1-4.

[3] Bresnihan, B., \& Stoops, B. (1996). Three ways that work! Oral fluency practice in the EFL classroom (Electronic version). English Teaching Forum, 34(3), 30.

[4] Brown, H.D. (2000). Principles of Language Learning and Teaching. White Plains, NY: Addison Wesley Longman, Inc.

[5] Brumfit, C. J. (1984). Communicative methodology in language teaching: The roles of fluency and accuracy. Cambridge University Press, Cambridge.

[6] Bygate, M. (1996). Effects of task repetition: Appraising the developing language of learners' in J. Willis and D. Willis (Eds.): Challenges and change $s$ in language teaching. Heinemann.

[7] Bygate, M., Skehan, P., and Swain, M., (Eds.). (2001). Researching pedagogic tasks, second language lerning, teaching and testing. Longman.

[8] Careless, D. (2004). Issues in teachers' reinterpretation of a task-based innovation in primary schools. TESOL Quarterly, 38(4), 662693.

[9] Chafe, W. L. (1980). Some reasons for hesitating. In H. W. Dechert \& Raupach (Eds.). Temporal variables in speech, 169-180.

[10] Dechert, H. W. (1980). Pauses and intonation of verbal planning in second language speech productions: Two examples from a case study. In H. W. Dechert \& M. Raupach (Eds.), Temporal variables in speech (pp.271-285).

[11] Derwing, T., Rossiter, M., Munro, M., and Thomson, R. (2004). Second language fluency: Judgments on different tasks. Language Learning, 54, 655-679.

[12]Ellis, N. (2001). Frequency effects in language processing: A review with implications for theories of implicit and explicit language acquisition. Studies in Second Language Acquisition, 24, 143-188.

[13] Ellis, R. (2003). Task-based language learning. Oxford University Press.

[14]Ellis, R. (2006). The methodology of task-based learning. Asian EFL journal, 8 (3), 19-45.

[15]Ellis, R. (2009). Task-based language teaching: sorting out the misunderstandings. International Journal of Applied Linguistics,19(3), 221-245.

[16]Freed, B. F., Segalowitz, N., \& Dewey, D. (2004). Context of learning and second language fluency in French: Comparing regular classroom, study abroad, and intensive domestic immersion programs. Studies in Second Language Acquisition, 26, 275-301.

[17] Hedge, T. (2000). Teaching and Learning in the Language Classroom. Oxford: Oxford University Press.

[18] Lewis, M. (2002). Implementing the Lexical Approach: Putting Theory into Practice. Boston, MA: Heinle.

[19] Littlewood, W. (2004). The task-based approach: some questions and suggestions. ELT Journal, 58,(4), 319-326.

[20] Littlewood, W. (2007). Communicative and taskbased language teaching in East Asian classrooms. Language Teaching, 40 (3), 243-249.

[21] Lynch, T. \& McLean, J. (2001). 'A case of exercising': Effects of immediate task repetition on learners' performance. In Bygate, Skehan \& Swain (Eds.).

[22] McLaughlin, B. (1990). Restructuring. Applied Linguistics, 11, pp. 113-128.

[23] Munro, M. J., and Derwing, T. M. (1998). The effects of speaking rate on listener evaluations of native and foreign accented speech (electronic version). Language Learning, 48 (2), 159-182.

[24] Nation, I.S.P. (2001). Learning Vocabulary in Another Language. Cambridge: Cambridge University Press.

[25] Nunan, D. (2003). The impact of English as a global language on educational policies and practices in the Asian-Pacific region.

[26] Porter, P., and Grant, M. (1992). Communicating effectively in English: Oral communication for non-native speakers (electronic version). Belmont: Wadsworth Publishing Company.

[27] Prabhu, N.S., (1987). Second language pedagogy. Oxford University Press. 
[28] Raupach, M. (1980). Temporal variables in first and secomd language speech production. In H.W. Dechert and M. Raupach (Eds.) Temporal variables in speech (pp. 49-60).

[29] Schegloff, E. \& Sacks, H. (1973). Opening up closings. Semiotics, 7, 289-327.

[30] Schmitt, N. \& Carter, R. (2004). Formulaic sequences in action: An introduction. In Schmitt, N. (Ed.). (2004). Formulaic Sequences, pp. 1-22. Amsterdam: John Benjamins Publishing Company.

[31] Schneider, P. (1997). Using Pair Taping. The Internet TESL Journal, III (2). Retrieved from http://iteslj.org/Techniques/Schneider-

PairTaping.html

[32] Schumann, J. (1999) Neurobiological perspective on affect and methodology in second language learning. In Arnold, J. (Ed.) Affect in Language Learning, pp. 28-42. Cambridge: Cambridge University Press.

[33] Tam, M. (1997). Building Fluency: A Course for Non-native Speakers of English. English Teaching Forum, 35 (1), 26.

[34] Temple, L. (1992). Disfluencies in learner speech. Australian Review of Applied Linguistics, 15, 2944.

[35] Towell, R. Hawkins, R., \& Bazergui, N. (1996). The development of fluency in advanced learners of French. Applied Linguistics, 17, 84-110.

[36] Turk, C. (1995). Effective speaking: Communicating in Speech. London: Chapman \& Hall.

[37] Wood, D. (2001, June). In Search of Fluency: What Is It and How Can We Teach It?. Canadian Modern Language Review, 57 (4), 573-589. 